\title{
NE-UTER OU UMA QUESTÃO DE GÊNERO: DO NEUTRO NA LÍNGUA À INSTABILILIZAÇÃO DOS GÊNEROS LITERÁRIOS
}

Márcia de Oliveira Reis Brandão

\section{Resumo}

Tendo como ponto de partida a categoria do "neutro" que foi objeto de artigo de Roland Barthes sobre Sarrasine, de Honoré de Balzac, e de seu curso ministrado no Collège de France, em 1978, este artigo propõe uma reflexão que vai da questão do gênero linguístico à problematização dos gêneros literários, que desde o século passado tornou-se um dos eixos do pensamento sobre a literatura. Como suporte, toma-se o texto Budapeste de Chico Buarque para tratar da questão, associando-a à linguagem e à escrita como uma experiência.

Palavras-chave: Gênero/Gêneros literários. Neutralidade. Experiência 
1 Na novela de Balzac, o narrador relata a um personagem feminino, surpreso com a figura de um ancião enfeitado e maquilado, a história de um escultor que se apaixona por uma cantora sem saber, na verdade, tratar-se de um castrado. Inspirado em sua figura, que reuniria em um único ser toda a beleza que até então só teria encontrado fragmentada, o artista esculpe uma estátua e pretende raptar a jovem para viverem um grande amor. Ao descobrir tratar-se de um castrado, enfurecido, tenta destruir a escultura e matar aquele que o enganara, mas termina assassinado por empregados do protetor do eunuco. $\mathrm{O}$ ancião é, na verdade, o castrado. Cf. BALZAC, H. Obras Completas, 1956, p.553587

2 A noção de composição está sendo por nós utilizada na acepção que Barthes lhe atribui no próprio artigo para referir-se à arte. Segundo o autor, esta constitui uma espécie de compósito capaz de reunir em uma única realização características contraditórias ou dispersas, sem que, entretanto, estas se anulem, apagando a diferença.

3 O foco do artigo está na questão da castração vinculada à ausência de marca, em oposição à presença, em determinadas formas linguísticas, como meio de constituir a significação. Sabemos, entretanto, conforme o próprio Barthes ressalta, na nota adiante reproduzida, que o tema da castração é basilar para a "Teoria da Sexualidade" proposta por Freud. De acordo com o Vocabulário da Psicanálise de Laplanche e Pontalis: “COMPLEXO DE CASTRAÇÃO - Complexo centrado no fantasma (fantasia) da castração, que vem trazer uma resposta ao enigma posto à criança pela diferença anatômica dos sexos (presença ou ausência

\section{I - O Neutro: do gênero linguístico aos gêneros literários}

Em "Masculino, Feminino, Neutro", Roland Barthes (BARTHES, 1976) dá início à análise, desenvolvida posteriormente em seu livro S/Z (1999), da novela Sarrasine, de Honoré de Balzac. ${ }^{1} \mathrm{O}$ artigo insere-se numa leitura estrutural da narrativa, procurando identificar os elementos que conduzem a possíveis interpretações do texto, pois, como o próprio autor declara, "esta novela comporta várias entradas" (BARTHES, 1976, p.12). Tais elementos estariam associados a determinadas perguntas que envolveriam "suspenses de ser" - "Quem é? / O que é?" e "suspenses de fazer" - "Quem fez?" / Qual será o desfecho dessa ação?". Essa estrutura regeria as obras que seguem um paradigma narrativo tradicional. $\mathrm{O}$ romance moderno, se não abandonou completamente essa forma de composição, a relegou para um plano contingencial. A ênfase se deslocou para o modo como o texto se constrói - e desconstrói - daí muitas vezes seu aspecto metaficcional, e sua última página, outras tantas vezes, longe de representar o seu fim, deixar a narrativa em aberto. De modo análogo, seus personagens adquirem função muito mais por sua "composição" do que por sua "definição". Na narrativa moderna, os personagens se apresentam multifacetados e em constante alteração, por esta razão, não importa defini-los, mas sim apresentá-los em sua complexidade, apontando para a subjetividade como algo em devir.

Segundo a leitura de Sarrasine proposta por Barthes no artigo, o texto seguiria o padrão narrativo tradicional, o que o leva a retomar em sua análise pressupostos da linguística. $\mathrm{O}$ autor assinala que, "a lingüística está fundada principalmente sobre a análise de modelos assertivos: a asserção representa a norma [...] e a interrogação o desvio (da mesma forma que a negação)" (BARTHES, 1976, p.5, parênteses do autor). O modelo assertivo, entretanto, seria, no caso das narrativas, um instrumento através do qual o modelo interrogativo (o suspense e sua decifração), fim último da narração, seria alimentado.

Embora destaque a importância desse modelo suspensivo - interrogativo - e o utilize para conduzir a leitura de Sarrasine, visando ao que denomina "decifração do texto", a ênfase, e a consequente relevância do artigo de Barthes, está na identificação de elementos do discurso que corroboram na construção do enigma da narrativa. São os signos de que essa se constitui que trazem para a pauta a questão do masculino/feminino/ neutro. São esses mesmos signos que confundem o personagem central da trama e, ao mesmo tempo, permitem deslindar seu enigma.

Tendo como eixo o personagem balzaquiano, a análise prioriza a relação entre o castrado ${ }^{3}$ e o neutro. Reportando-se sempre à questão linguística, Barthes assinala que, assim como 
Continuação nota 3

de pênis): esta diferença é atribuída a um corte do pênis da criança do sexo feminino. A estrutura e os efeitos do complexo de castração são diferentes no rapaz e na menina. $\mathrm{O}$ rapaz teme a castração como realização de uma ameaça paterna em resposta às suas atividades sexuais, do que lhe advém uma intensa angústia da castração. Na menina, a ausência do pênis é sentida como um dano sofrido que ela procura negar, compensar ou reparar" (LAPLANCHE; PONTALIS, 1983, p.111). Barthes: "Na perspectiva de uma análise psicológica - que não é a deste estudo - seria fácil mostrar que Sarrasine ama em Zambinella o próprio castrado; notaríamos então sua agressividade em relação àquilo que ele acredita portanto ser uma mulher; sua insistência em declarar que ama em Zambinella aquilo que a faz um castrado ("Oh! Frágil criatura! Como poderia ser diferente?" e até a feminilidade mesma do nome Sarrasine, escolhido contra o masculino correntemente atestado pelo onomástico francês (Sarrazin) (BARTHES, 1976, p.14)". Nos dois casos, entretanto, o aspecto determinante é a vinculação do tema da castração e do neutro a um menos, a uma falta, a uma ausência. ocorre com o castrado, o que marca o neutro na língua francesa seria uma falta, instaurada devido ao padrão binário sexual masculino/feminino - institucionalizado. A distinção, na verdade, que a língua fracassa em reproduzir ("se a ausência de marca faz dela o feminino, de que poderia ser feito o neutro?" (BARTHES, 1976, p.10)), não é sexual e sim entre "animado" e "inanimado". O centro do texto deslocar-se-ia, então, da questão sexual para a da vida: Sarrasine, finalmente, quando decifra o enigma, é incapaz de proferi-lo e... morre. Essa é a metáfora da novela, nos diz Barthes:

A segunda pergunta (Quê?) dá à novela toda a sua especialidade. É ainda o ancião, e é principalmente Zambinella que a representam: de que natureza são eles? A pergunta, para falar a verdade, não tem por objetivo uma escolha de nomes, mas a possibilidade mesma da nomeação: o que é sugerido, a título interrogativo, é antes de tudo a categoria do inominável, da coisa, no sentido fantástico do termo; o suspense de ser, aqui, não é ignorância, mas enigma: o ancião atemoriza como uma coisa de que não se pode achar o nome (ele amedronta, não se pode tocá-lo), e Sarrasine morre quando pode dar a Zambinella seu verdadeiro nome: de todas as coisas, ela é a mais terrível, ela é o nada... (BARTHES, 1976, p.6, grifos do autor).

A questão do neutro na novela está prioritariamente vinculada ao discurso enquanto atualização da língua, pois, conforme assinala o autor relembrando o padrão assertivo da língua francesa, ele, o neutro, não é o inexpressivo, mas o morfologicamente não-marcado. No texto metaforizado na figura do castrado, ele é, portanto, aquilo que não pode ser nomeado, e, no universo predominantemente linguístico do homem, o que não pode ser nomeado é nada.

$\mathrm{O}$ personagem Zambinella, o neutro, representa, em Sarrasine, a privação da vida, e, finalmente, a privação da arte. O prólogo do texto é responsável por iniciar o jogo que a narrativa implementará a partir dos contrastes entre feminino e masculino, calor e frio, vida e morte. A pintura de um Adônis, feita com base na escultura, que posteriormente sabemos ser a re-criação de Zambinella por Sarrasine, é considerada, por uma das personagens, perfeita demais para representar um homem. Barthes retoma, então, a partir das duas modalidades artísticas, a pintura e a escultura, a relação entre superfície e profundidade:

Poder-se-ia dizer que a estátua, comportando uma espessura a ser investigada, arrasta o escultor a uma paixão da decifração e à verdade do referente, enquanto a pintura (feita por outro, não se deve esquecer) sendo imediata, sem profundidade, sem reverso e sem coração, retém o artista na verdade da ilusão; pintor, Sarrasine não tentou virar a tela e não arriscou descobrir ali com horror o nada de seu segredo... (BARTHES, 1976, p.14, grifos do autor). 
Assim como a pintura, a arte da escrita, em oposição à escultura, também estaria no nível da superfície, tendo em vista o aspecto sucessivo da linguagem, por esta razão, a narrativa partilharia com o personagem Sarrasine o processo de reconhecimento quanto à situação do castrado. Primeiramente, este seria apresentado com as marcas linguísticas do feminino [a Zambinella], enquanto esta é, para o protagonista, uma mulher, passando, então, à ausência de marca [Zambinella] quando é revelada a sua real condição.

O tema do neutro, como apagamento de marcas pautadas na oposição paradigmática, apontando para a indeterminação e mobilizando a falta, discutido no artigo, retorna em O Grau Zero da Escrita (BARTHES, 2004). Segundo Barthes, a forma narrativa aproximaria as escritas romanesca e histórica. O autor destaca o uso do passé simple em francês para a escrita do romance. Esse tempo verbal, ausente da linguagem oral, reuniria características especiais e determinantes para distinguir a escrita. Um dos aspectos mais importantes do uso do passé simple, é que este, ao abolir a duração, especialmente no caso da escrita da História, destituiria a realidade de sua espessura. Ao abstrair a duração, a forma romanesca excluiria o conflito, a tensão entre os tempos, integrando o sistema de segurança das Belas Letras, que se manteria inalterado e portador do sentido. De modo análogo, a adoção da terceira pessoa permitiria alcançar-se a imparcialidade necessária para a verossimilhança da narração, integrando também tal sistema.

É exatamente a espessura da escrita, seu mergulho em usos precedentes - "a linguagem nunca é inocente: as palavras têm uma memória segunda que se prolonga misteriosamente no meio das significações novas" (BARTHES, 2004, p.15) - que, paradoxalmente, leva o pensador a postular para ela um grau zero ou a neutralidade. O que se denomina como escrita neutra é uma escrita sem marcas pré-determinadas, que se afasta de um projeto realista-naturalista revelado como artificial. O próprio Barthes, entretanto, reconhece a utopia de uma escrita neutra ou branca:

[...] nessas escritas neutras, chamadas aqui "o grau zero da escrita", pode-se facilmente discernir o movimento mesmo de uma negação, e a impotência de completá-la num lapso de tempo, como se a Literatura, tendente há um século a transmudar a sua superfície numa forma sem hereditariedade, não mais encontrasse pureza a não ser na ausência de todo signo, propondo enfim o cumprimento desse sonho órfico: um escritor sem literatura (BARTHES, 2004, p.6-7, grifo nosso).

Do reconhecimento da impossibilidade de se alcançar "o grau zero", o autor retoma o "Neutro" como uma categoria que envolve uma pluralidade de significados. Da relação linguística entre animado e inanimado, foco da análise em seu artigo inau- 
gural, buscará identificar enunciadores do que denominou de "Neutro" ou, mais precisamente, "desejo de neutro" (BARTHES, 2003 b, p.5). O autor traz, então, para a cena, a possibilidade de promoverem-se infinitos deslocamentos e substituições de significados. O que concebe como "Neutro" é antes uma travessia. Assim, para apresentá-lo, durante curso ministrado no Collège de France, elege vinte e três figuras pelas quais declara "passear o neutro" (BARTHES, 2003b, p.21) e que constituiriam atualizações de seu tema. Na abordagem de tais figuras, germinam outras, criando-se não só uma rede de leituras, mas uma rede de significados que se suplementam continuamente. Barthes, ele mesmo o declara, exibe (apresenta) "Neutros". A categoria proposta pelo autor, portanto, será marcada pelo paradoxo: simultaneamente menos e plural, manifestando-se através da multiplicidade das figurações propostas.

Entre estas, o matiz entre "taceo e sileo" é analisado como constituinte da figura "silêncio". O termo latino sileo estaria associado ao estado físico das coisas, ausência de movimento, ruído - "Em suma, silere remeteria de preferência a uma estado de virgindade perene das coisas, antes de nascerem ou depois de desaparecerem (silentes $=$ os mortos)" (BARTHES, 2003b, p.49) - enquanto taceo, do verbo Tacere, representaria a ausência de fala, relacionando-se ao discurso enquanto traço distintivo do homem.

A relação entre a morte, o silêncio e o neutro é também destacada na abertura de seu curso, quando Barthes informa que a reflexão será alimentada por autores que já faleceram e declara se sentir dilacerado pelo contraste entre a vitalidade de suas obras e a tristeza de sabê-los mortos. Note-se, entretanto, que a postulação da "morte do autor" como forma de afirmar a prevalência do texto, da matéria escrita, então denominada "escrita neutra", já se fizera força motriz de artigo homônimo. Também em "Da obra ao texto" (BARTHES, 1987b), o pensador procurava apontar a necessidade de afastar-se a figura do autor, que a partir da valorização do indivíduo pela ideologia capitalista teria quase sido transformada em instituição, para que se deixasse falar a linguagem. No que tange à sua vinculação com o neutro, a morte seria o ápice da neutralidade, não remetendo, entretanto, à extinção da possibilidade de significação, mas sim para a dissolução do conflito, mantendo ativa a relação fundamental à qual remete o "neutro": vida e morte, já enfatizada no artigo sobre Sarrasine.

É importante notar que suas proposições sobre o "neutro" permitem desconstruir a visão tradicional que o concebe como ausência de posição, imobilismo. O neutro barthesiano não é o inexpressivo. $\mathrm{O}$ autor resgata a categoria como alternativa à determinação, como forma de evitar o conflito porque este, segundo indica, mantém a ordem opositiva $\square$ "ou isto ou aquilo" 
predominante na cultura ocidental. Na relação entre animado e inanimado, vida e morte, que desde o artigo inaugural sobre o tema foi dado central de sua perspectiva interpretativa, esses elementos são concebidos como complementares e não excludentes.

O "Neutro", portanto, remete sim a uma indeterminação, está "entre o sim e o não", como estamos, todos, após a derrocada das certezas que predominaram até a época moderna. Mas, como diz o próprio autor no resumo que elaborou para o anuário do Collège de France: "o Neutro não corresponde obrigatoriamente à imagem pobre essencialmente depreciada que dele faz a dóxa, mas pode constituir um valor forte, ativo" (BARTHES, 2003b, p.431). O que a categoria acentua é a possibilidade de variação contínua, de se atualizar em múltiplas figurações, sendo, portanto, não um devir em, mas sim um devir-devir.

\section{II - A instabilização dos gêneros em Budapeste, de Chico Buarque}

A escrita é esse neutro, esse compósito, esse oblíquo para onde foge o nosso sujeito, o preto-e-branco aonde vem perder-se toda a identidade, a começar precisamente pela do corpo que escreve (BARTHES, 1987a, p.49).

Como infância do homem, a experiência é a simples diferença entre humano e lingüístico. Que o homem não seja sempre já falante, que ele tenha sido e seja ainda in-fante, isto é a experiência (AGAMBEN, 2005, p. 62).

Budapeste, terceiro romance de Chico Buarque traz para a cena a figura de um ghost-writer. José Costa, narrador-protagonista, é um Doutor em Letras que se dedica a escrever textos dos mais diversos tipos por encomenda, atividade que desenvolve sob a chancela de uma agência da qual é sócio juntamente com um amigo de juventude. Casado com Vanda, uma apresentadora de telejornal, com quem tem um filho, parece satisfeito com o anonimato e com a vida sem grandes emoções, apenas perturbada pela vaidade que, às vezes, lhe sobe à cabeça. Tal sentimento se manifesta de forma paradoxal: o narrador se regozija em saber que aqueles textos apreciados e cuja autoria é sua são considerados obras de outros, mas ao mesmo tempo parece ressentir-se da falta de reconhecimento.

A relação que mantém com a escrita parece abalar-se definitivamente a partir de seu contato com uma língua estrangeira: o húngaro. Ao ser forçado, devido a problemas no avião, a pernoitar na cidade de Budapeste quando retornava de um encontro internacional exatamente de ghost-writers, o narrador se surpreende com aquela língua forte, mas que não compreende, e pouco a pouco é tomado por uma espécie de fascinação pelo que lhe parece inapreensível. 
A parada em Budapeste e as emoções experimentadas face ao contato inicial com a língua magiar constituem o primeiro capítulo do romance, marcado pela concisão, pelo confinamento do narrador ao espaço do hotel e inaugurado por uma projeção a um tempo futuro na narrativa, quando retorna à cidade, conhece Kriska, que então se torna sua professora de húngaro, e começa junto a ela uma nova vida.

Em Infância e História, Giorgio Agamben (AGAMBEN, 2005) destaca o que denomina "infância" como uma experiência seminal para a constituição da história. A "infância" não se restringiria a uma etapa cronológica determinada na vida do homem. Embora possa ser associada a um espaço-tempo específico da existência, o que a caracterizaria prioritariamente seria a experiência. Retomando a análise desenvolvida por Benjamin sobre a experiência a partir da Modernidade, e consequentemente da função da narrativa como meio de transmiti-la, Agamben aponta para a perda, na época contemporânea, da possibilidade de uma experiência originária. Esta passa, então, a ser vivenciada apenas no ato do homem ingressar na linguagem:

Uma experiência originária, portanto, longe de ser algo subjetivo, não poderia ser nada além daquilo que, no homem, está antes do sujeito, vale dizer, antes da linguagem: uma experiência "muda", no sentido literal do termo, uma in-fância do homem, da qual a linguagem deveria, precisamente, assinalar o limite" (AGAMBEN, 2005, p.58).

Agamben deixa claro que o que postula como "infância" é uma forma dotada de especificidade que, simultaneamente, é testemunho da cisão entre língua e discurso, entre "in-fante" e "sujeito" e remete a uma experiência que continuamente repete o ingresso do homem na linguagem. O homem estaria, assim, sempre à beira /à margem da linguagem e o silêncio não seria o seu negativo, mas parte dela com seus vazios, lacunas e hesitações.

A breve estada do narrador em Budapeste e os sentimentos de estranhamento e privação experimentados no contato com a língua húngara parecem remeter exatamente a esse espaçotempo. É o que o narrador parece buscar nas primeiras páginas do texto, diante da TV. Enquanto assiste ao noticiário, ao perceber que durante uma entrevista outra língua surgiria, o narrador retira o volume, concentrando-se na grafia das legendas, a fim de evitar a interferência de outras naquela que lhe parece, a princípio, a mais estrangeira de todas as línguas:

Aí entrou na tela uma moça de xale vermelho e coque negro, ameaçou falar espanhol, zapeei no susto [...] Cortei o som, me fixei nas legendas, e observando em letras pela primeira vez palavras húngaras, tive a impressão de ver seus esqueletos: ö az álom elötti talajon táncol (BUARQUE, 2003, p.9). 
O segundo capítulo traz novamente o aparato televisivo como ponto de partida. Entretanto, se no capítulo de abertura ele é responsável pelo choque causado no contato com o húngaro, aqui ele testemunha uma espécie de imobilidade em que se encontra o narrador, acentuada pelo fato de que quem "está" na TV é sua própria mulher: "A narração estava arrastada, a voz sem brilho, com certeza a Vanda tinha gravado aquele texto de manhã bem cedo" (BARTHES, 2003, p.13). É nesse capítulo que se dá a conhecer a história de José Costa e se indicia a relação entre a questão da escrita e da autoria - e dos gêneros literários - e a fragmentação da subjetividade que serão mobilizadas no texto. Conforme destaca Agamben, quando a criança diz "eu", marca-se o ingresso do homem na linguagem:

Os animais não entram na língua: já estão sempre nela. O homem, ao invés disso, na medida em que tem uma infância, em que não é já sempre falante, cinde esta língua una e apresentase como aquele que, para falar, deve constituir-se como sujeito da linguagem, deve dizer "eu" (AGAMBEN, 2005, p.64).

Em Budapeste, o protagonista parece exatamente recusar esse gesto de ingresso e permanência na linguagem ao abdicar de dizer "eu", ou, este escrito é "meu" a partir da função de ghost-writer que adota. Entretanto, o romance é narrado em primeira-pessoa, aproximando-se de uma escrita mais "autoral". Implementa-se, assim, um jogo ficcional a partir do contraste entre a tematização da autoria e a forma de composição da narrativa.

A questão da autoria vinculada à constituição da subjetividade e da alteridade, já revelada através de sua atividade profissional, desdobra-se de forma mais explícita nos episódios da terceirização dos serviços, antes exclusivos do narrador, quando seu sócio contrata outros redatores para a agência:

Quando me vi cercado de sete redatores, todos de camisas listradas como as minhas, com óculos de leitura iguais aos meus, todos com meu penteado, meus cigarros e minha tosse, me mudei para um quartinho que estava servindo de depósito atrás da sala de recepção. Ali recuperei o gosto pela escrita, pois os artigos para a imprensa me deprimiam, eu já tinha a impressão de estar imitando meus êmulos. Passei a criar autobiografias, no que o Álvaro me apoiou, afirmando tratar-se de mercadoria com farta demanda reprimida (BUARQUE, 2003, p.25).

Segundo Émile Benveniste (1976), as formas pronominais pessoais ["eu", "tu", "ele"] constituem realidades exclusivamente linguísticas. Elas não remetem nem a um conceito nem a um indivíduo, simplesmente indicam as pessoas do discurso. No caso da forma pronominal "ele" ("ela"), nos diz Benveniste, "seu valor está em ser parte de um discurso enunciado por um "eu"'". A forma "ele", portanto, não se refere nem mesmo ao 
objeto ("tu"/"te") a quem o discurso se dirige. A terceira pessoa (pronominal), portanto, está em completa posição de alteridade no que tange à elocução (BENVENISTE, 1976, p.286).

Em Budapeste, a questão do "ele" associa-se à dupla terceirização do ato da escrita, pois o narrador não só escreve para outros, assim como passa a ter outros a escreverem em seu lugar, reproduzindo não só o seu estilo, mas também sua aparência. No episódio, portanto, a inserção dessa terceira pessoa não aponta para o reconhecimento da alteridade ou do aspecto fragmentário da subjetividade, mas reafirma a uniformização através da busca da cópia do estilo, da imagem.

A produção em série, não só de textos, mas também de escritores de textos no romance, todos à "imagem" e "letra" do narrador, nos remete a uma relação de total reversibilidade entre criador e criatura, levando o protagonista a pensar que era ele a cópia. Não só a escrita, mas o próprio estilo transformam-se em algo passível de reprodução infinita, transformam-se, como atesta a última parte do fragmento, em mercadoria, em demanda reprimida. Ironicamente, para escapar a essa situação o narrador decide criar... autobiografias.

A decisão do narrador de "criar a história da vida" de outros permite aclarar a fragilidade das fronteiras entre o real e o ficcional, tema caro à reflexão literária desde a Modernidade, e um dos eixos principais de Budapeste. As noções de gêneros também são perspectivadas, pois a escrita autobiográfica, concebida como o registro da verdade ou "história" de uma vida, desvela-se como ficção. Com o enfraquecimento da oposição paradigmática entre interioridade e exterioridade como aspecto distintivo para a configuração da subjetividade, esta passou a ser concebida como processo: perpassa e é perpassada por diversas forças sociais, culturais, históricas. Por esta razão, se no período de apogeu do capitalismo a afirmação da individualidade estava ligada ao dizer "eu" e remetia a uma determinação, a instabilização dos limites pôs em xeque a própria noção de sujeito. Se a decisão do

4 Conforme destaca Florencia Garramuño (2009), Agamben tem na reflexão desenvolvida por Walter Benjamin, especialmente nos textos já mencionados no presente trabalho, "Experiência e pobreza" e "O narrador", nos quais analisa as relações entre a experiência e a arte de narrar a partir das transformações ocorridas no século XIX, o ponto de partida de suas proposições. Cf. BENJAMIN, W. Magia e técnica, arte e política; ensaios sobre literatura e história da cultura, 1994. narrador a princípio parece irônica, ela atesta mais uma vez a perda da autoridade que estaria implicada não só na narrativa, mas principalmente na suposta narrativa de uma vida.

Agamben, ao postular a infância como a forma da experiência na época moderna, assinala não a ausência em si do que experimentar, mas, exatamente, a perda da autoridade que sempre esteve implicada no ato de transformá-la em narrativa e, assim, transmiti-la a outros, como propunha Benjamin:

Porque a experiência tem o seu necessário correlato não no conhecimento, mas na autoridade, ou seja, na palavra e no conto, e hoje ninguém mais parece dispor de autoridade suficiente para garantir uma experiência, e se dela dispõe, nem ao menos o aflora a idéia de fundamentar em uma experiência a própria autoridade (BENJAMIN, 1994, p.23). ${ }^{4}$ 
${ }^{5 " A}$ comprovação científica da experiência que se efetua no experimento - permitindo traduzir as impressões sensíveis na exatidão de determinações quantitativas e, assim, prever impressões futuras responde a essa perda de certeza transferindo a experiência o mais completamente possível para fora do homem: aos instrumentos e aos números" (AGAMBEN, G., 2005, p.23) e “[...] não significa que hoje não existam mais experiências. Mas estas se efetuam fora do homem. E, curiosamente, o homem olha para elas com alívio. Uma visita a um museu ou a um lugar de peregrinação turística é, desse ponto de vista, particularmente instrutiva. Posta diante das maiores maravilhas da terra (digamos, o pátio de los leones, no Alhambra) a esmagadora maioria da humanidade recusa-se hoje a experimentá-las: prefere que seja a máquina fotográfica a ter experiência delas" (AGAMBEN, G., 2005, p.26).
Embora assinale a passagem da experiência para fora do homem, ou seja, a partir da ascensão da Ciência Moderna e, consequentemente, do discurso científico, o que há são "experimentos" ${ }^{5}$ e não mais "experiência", o autor prefere não adotar uma postura saudosista e vislumbrar nesse processo, quem sabe, "o germe de uma experiência futura" (AGAMBEN, 2005, p.23), da qual, entretanto, nada se pode prever.

Na verdade, a experiência não foi extinta, mas sim transformou-se e também a forma de interpretá-la e tematizá-la. Ao falar na sua transferência para "fora" do homem, Agamben pode ser aproximado das observações de Silviano Santiago (1989) sobre o narrador pós-moderno como "narrador-observador". Nas narrativas que este produz o que importa não é transmitir uma experiência, apontando para a imobilização do vivido, mas sim ser ponto de partida para outras experiências, contribuindo, assim para a produção histórica.

Em "A morte do autor" e "Da obra ao texto", por nós já mencionados, Barthes assinala a escrita como forma de atualização de um neutro. Segundo destaca, a figura do autor é criação moderna, vinculada ao prestígio individual - que se afirmou com a ascensão do capitalismo - e ao mito do sujeito enquanto identidade constante. Para o autor, a literatura é a forma de abdicar da arrogância, de atualizar a neutralidade, e isso só é possível quando se reconhece sua "condição essencialmente verbal" (BARTHES, 1987a, p.50).

Para Barthes a obra é um todo fechado, cujo sentido está imobilizado, instituído. Nesse contexto, o binômio "obra-autor" parece indissociável. Ao se perspectivar a noção de obra, surge um objeto novo: o texto. Este, dotado de materialidade formal, está em contínua produção, "seu movimento constitutivo é a travessia" (BARTHES, 1987b, p. 56, grifo do autor). Barthes reafirma a escrita enquanto forma própria de tematização da realidade, sem, entretanto, ter como fim reproduzi-la - mais uma vez estamos no terreno da mímesis de produção -, mas recusa a leitura vida e obra nos moldes realistas que visava ao estabelecimento de relações de causalidade e reversibilidade entre a escrita e o seu autor.

Essa forma de conceber a relação autor/texto está em consonância com as proposições de Garramuño ao tratar da relação entre arte e contexto na época modernista e na contemporaneidade. Mobilizando os conceitos de autonomia e heteronomia, a autora destaca que o período modernista, através da radicalização de práticas vanguardistas, buscava afirmar a arte em uma relação de autonomia para com a realidade. Diferentemente, as manifestações contemporâneas apontariam para a heteronomia. Isto é, reconhecendo o contexto como referência elas não o reproduziriam, mas a partir da diferença que instaurariam face a ele permitiriam sua mediatização e crítica. Esse processo 
implicaria a desauratização da arte e, consequentemente, a perda do caráter redentor da realidade de que ela seria portadora. Admitir a heteronomia do texto também implica reinserir a experiência no processo de elaboração do ficcional que incorpora, então, o aspecto fragmentário daquela (GARRAMUÑO, 2009). Assim, tanto a experiência quanto a narrativa perdem seu caráter acumulativo, e "percebe-se como se tornou impossível dar continuidade linear ao processo de aprimoramento do homem e da sociedade" (SANTIAGO, 1989, p. 46).

A mobilização da figura do ghost-writer e da relação que se estabelece entre o narrador e a escrita em Budapeste permite pôr em xeque exatamente a autoria como afirmação da identidade e da autoridade. O texto implementa um jogo a partir das constantes observações do próprio narrador quanto à preferência pelo anonimato que se contrapõem ao desagrado de ver-se cercado por cópias suas, não tanto no aspecto físico, mas no estilo. $O$ fato de saber-se "totalmente" reproduzível apontaria, assim, para a perda completa da autoria e da autoridade que só o domínio da língua é capaz de prover. Mas essa "renúncia" à autoria, a ser reconhecido, é complexa, como revelam o sentimento de vaidade e o ressentimento pela indiferença de sua mulher aos seus escritos:

Referências de viva voz a meu trabalho, elogiosas ou não, aprendi a ouvi-las impassível, desde o tempo em que me misturava ao povo para acompanhar discursos políticos recémescritos. Já quando comecei a escrever para a imprensa, me aprazia entrar nesses bares de Copacabana, onde homens solitários passam a tarde a tomar chope e ler os jornais. Caso encontrasse alguém entretido com um artigo meu, me sentava à mesa ao lado, e era quase certo que daí a pouco o sujeito comentasse o texto comigo, longe de suspeitar que fosse eu o autor [...] depois de casado, nos dias em que estava seguro de haver escrito um texto com grande inspiração, eu dispensava a opinião dos botequins; meu desejo era de que a Vanda o lesse (BUARQUE, 2003, p.102-103).

Seja na língua materna, seja no húngaro, o narrador, simultaneamente renuncia à autoria e parece buscar o reconhecimento. Na narrativa, tal necessidade é explicitada tanto por seu desejo de que Vanda reconheça o valor de seus textos, ou ao menos que os leia, quanto no de que Kriska "reconheça" seu domínio da língua húngara. As figuras de Vanda e Kriska - respectivamente sua mulher e sua amante na Hungria - embora remetam à mulher amada, constituem, assim, metáforas da figura do leitor. Tal desejo, embora aparentemente se oponha à tese da escrita como neutro, justamente ao mobilizar a figura do leitor revela-se em consonância com o que ela envolve e desvela o paradoxo de querer-se anônimo e reconhecido, também implicado, conforme mencionamos, em sua decisão de dedicar-se a escrever as 
memórias de outros. Ao fazê-lo, o narrador resolve consagrar-se a "atender somente personagens tão obscuros quanto eu [ele]" (BUARQUE, 2003, p.25).

A publicação das "memórias romanceadas" (BUARQUE, 2003, p.33) do alemão Kaspar Krabbe introduzirá uma ruptura nessa ordem. A autobiografia criada por José Costa transformase em sucesso editorial, subvertendo a proposição do narrador. A redação da autobiografia inicialmente traz à tona o processo de escrita como um "por vir", marcado pela indeterminação. Apesar de contar com as fitas com o relato do alemão, o que poderia associar-se à ideia de um roteiro, um projeto a seguir, mais uma vez a falta se desvela na dificuldade que José Costa experimenta na criação do texto. Embora disponha de matéria a ser contada, o narrador "hesita" ao escrever: "[...] esse meu texto estava viciado, patinava, não evoluía. Alguma coisa me atrapalhava, palavras bizarras me vinham à mente, eu esfolava os dedos no teclado $\mathrm{e}$ no fim da noite jogava o trabalho fora" (BUARQUE, 2003, p.30). Finalmente, quando consegue escrever, o livro torna-se um fenômeno editorial. Importa notar que as "memórias" do alemão constituem, salvo alguns dados factuais, "totalmente ficção", pois o narrador declara nem mesmo ter retomado as gravações que este lhe deixara. No processo de composição do livro, o narrador e o personagem - o alemão - fundem-se e o personagem narrador-alemão também é transformado em escriba.

O processo de escrita/aprendizagem da língua portuguesa pelo estrangeiro se dá através da escrita em um papel especial: o corpo de mulher. Teresa se associa ao branco da folha de papel. Um duplo de Kriska (ou vice-versa) sobre quem declara o narrador: "[...] eu nunca tinha visto corpo tão branco em minha vida. Era tão branca toda a sua pele que eu não saberia como pegá-la, onde instalar as minhas mãos" (BUARQUE, 2003, p.45). Quando Teresa nega o seu corpo à escrita, o alemão, após a impossibilidade de usar o meio habitual, o papel, desliza de prostitutas a estudantes, transformadas em papel-tela no qual escreve, pinta sua história. A relação de especularidade - José Costa repete, na Hungria, a mesma atividade profissional, repete, em seu relacionamento com Kriska, seu casamento com Vanda, ambos marcados por inexplicáveis e repetidos abandonos, indicia-se, então, na figura daquela que lhe ensina a escrever de trás para diante, o que faz do espelho aparato exigido para a decifração.

Como Penélope da Odisséia, a personagem sem nome que substitui Teresa em sua função de folha em branco também desfaz o tecido/escrito; como Sherazade, das Mil e Uma Noites, ela mantém a suspensão:

Zelosa dos meus escritos, só ela os sabia ler, mirando-se no espelho, e de noite apagava o que de dia fora escrito, para que eu jamais cessasse de escrever meu livro nela. E engravidou 
de mim, e na sua barriga o livro foi ganhando novas formas... (BUARQUE, 2003, p.40).

Essa mulher e o ex-marido de Kriska são os únicos personagens dotados de importância na narrativa a não serem nomeados. No caso do ex-marido da húngara, "o Sr....", ao final da narrativa revela-se ser também ele, como o narrador-protagonista, um ghost-writer e o autor da autobiografia intitulada Budapeste que "narra" justamente a história de Zsoze Kósta, um ghost-writer brasileiro que, entre idas e vindas, retira-se definitivamente para a Hungria. A escrita da vida de Costa/ Kósta pelo ex-marido de Kriska constitui o ápice do processo de desconstrução/instabilização da autoria, da identidade e dos gêneros literários, implementado pela narrativa, explicitado na estupefação do protagonista ante a materialidade do livro em suas mãos quando retorna definitivamente (?) para Budapeste: "A capa furta-cor, eu não entendia a cor daquela capa, o título Budapest, eu não entendia o nome Zsoze Kósta ali impresso, eu não tinha escrito aquele livro" (BUARQUE, 2003, p.167, grifo nosso). A notoriedade, o reconhecimento que José Costa buscara e recusara quase simultaneamente com a sua escrita anônima lhe vêm, de repente, a partir do texto de um outro, repetindo-se em sua vida o que ele fizera à de outros.

No caso daquela que oferece seu corpo à escrita, silencia-se o seu nome, assim como ela apaga o escrito, fazendo retornar o vazio, que se transforma em contínua força motriz. A ausência de nome reproduz a própria condição do texto que José Costa escreve para o alemão, sem "autor verdadeiro" - e, afinal, autobiografia, romance, ficção de uma vida? -, a indicar que a história da vida que se conta, que se inventa, pode ser a de qualquer um, que o texto, uma vez escrito, liberta-se da necessidade de portar um nome.

A escrita no corpo implica múltiplos aspectos. Em uma época em que se recusa a experiência do próprio espaço, transferida para máquinas fotográficas ou para viagens virtuais, trazer de volta o corpo com sua carnadura, com sua concretude, aponta para a possibilidade de retomá-la, de retornar à existência cotidiana. Se a unificação do conhecimento e da experiência "inverteu a ordem dos fatos" e primeiro se estabelece uma hipótese para depois comprová-la, o recurso ao corpo pode indicar o caminho inverso, como a escrita do alemão feita de trás para diante. De modo análogo, o modo invertido de escrever, assim como a retomada de frases, de cenas e situações com pequenas variações no romance ${ }^{6}$ inserem a repetição e a circularidade no texto e a põem em xeque a noção teleológica de futuro. Não se vai em direção a fim algum; não há desfecho. Início e fim se confundem. A escrita no corpo - assim como o próprio corpo, unidade orgânica e fragmento - remete simultaneamente à 
identidade fraturada do sujeito e à pluralidade do real, ambos em devir, e o que importa é a trajetória, o movimento da escrita, da História.

Se o corpo das mulheres se transforma em papel-tela, o corpo do alemão Kasper Kraber, na história que Costa inventa para ele, é também papel sem tinta, pois, devido ao choque quando deparou-se com a terra estrangeira, perdera as linhas, os traços que os pelos traçam no corpo. Sem pelos, ou com poucos pelos como muitos bebês. Como os bebês, muitas vezes, indefiníveis: menino ou menina? O personagem do alemão se aproxima do castrado da novela de Balzac: neutro. Kraber é também retorno à infância, pois não só se inicia em outra língua, assim como, por seu aspecto, aproxima-se do estágio inicial da vida.

"Aquele que escreve em mulheres". "O Ginógrafo" é o título do livro. A própria narrativa aproxima os vocábulos "ginógrafo" e "naufrágio": No fim da narrativa, quando expulso da Hungria, José Costa volta ao Brasil e procura pelo "seu" livro, o que encontra é uma publicação intitulada O Naufrágio. Quase compostos pelos mesmos grafemas e fonemas, os dois termos se vinculam tanto ao personagem que o narrador cria para o alemão quanto à sua própria história. Dado sutil da narrativa, Costa nos revela que o ariano viera para o Brasil de navio. Cinco vezes a narrativa repete: "sete anos atrás, quando zarpei de Hamburgo e adentrei a baía de Guanabara" (BUARQUE, 2003, p.29) [duas vezes]; (BUARQUE, 2003, p.30) [duas vezes] e (BUARQUE, 2003, p.38) [uma vez]. Naúfrago parece sentir-se o alemão ao primeiro contato com a terra estrangeira, que o leva a cair de cama e ao acordar encontrar-se sem pelos. Viagem, naufrágio, deriva.

A ideia de um tecido-escrita que se escreve e se apaga continuamente assim como a hesitação que o narrador de Budapeste parece experimentar entre o Rio e a capital húngara instauram o silêncio na narrativa como uma espécie de ritmo, movimento de ir e vir, que se aproxima daquele executado pelo protagonista do primeiro romance de Chico Buarque. Após escrever o livro, é nosso narrador quem se lança à deriva. E duplica, através de trajetória inversa, a história que criara para o alemão. Inicia o seu movimento de repetidas retiradas entre as duas cidades.

É a revelação de sua mulher de que os sons ininteligíveis emitidos por seu filho eram reprodução de sua fala no sono que faz retornar ao narrador a estupefação que lhe causara a língua húngara: "E hoje aquela Budapeste estaria morta e sepultada, não fosse o menino levantá-la do meu sonho" (BUARQUE, 2003, p.31) e motivar sua partida para a cidade. O filho de José Costa é uma criança de cinco anos que parece sofrer de um tipo de afasia, pois fala pouquíssimas palavras, o que o preocupa. O fato de que, apesar de não (ou pouco) falar, a criança reproduza os fonemas que o narrador também fora somente capaz de repro- 
duzir, durante e após a estada em Budapeste, se aproxima do que Agamben denomina experimentum linguae. Assim como seu filho ainda não ingressara no universo da linguagem, também o narrador experimenta situação análoga quanto ao húngaro. Metáfora desvelada, seu filho é duplamente infância: mudo na própria língua; articulador de sons na língua estrangeira.

Assim como a subjetividade só se dá a partir do ingresso na linguagem, o sentimento de nacionalidade, de pertencer a um lugar, tem na língua pátria, talvez mais do que no espaço, a sua base. Na narrativa, Costa, ao emitir tais palavras, assim como seu filho, este duplamente in-fante, se aproximam desse estágio inicial. Capazes de reproduzir os fonemas de todas as línguas, não têm língua alguma, não pertencem a nenhum lugar. Mantém-se assim a u-topia, o "não-lugar". Ao partir para Budapeste, o narrador assume verdadeiramente a condição de in-fante.

A impossibilidade da conquista de um domínio perfeito do húngaro, traduzida na denominação de seu poema como exótico e, finalmente, o reconhecimento e autoria compulsórios a partir de um texto cuja autoria, apesar de publicamente negar - "O autor do meu livro não sou eu, me escusei no Clube das Belas-Letras, mas todos fizeram festa e fingiram não me ouvir" (BUARQUE, 2003, p. 170) - permanece como sua, mantêm a falta e simultaneamente revelam o fracasso dos projetos de José Costa, apontando para a impossibilidade de fazer-se do tempo por vir algo previsível. É, talvez, esse fracasso que o ritmo fragmentado da narrativa com os repetidos abandonos e retiradas do narrador, instituído na história narrada, atualize. Talvez por isso o próprio Costa/Kósta encontre no sono/sonho a forma de burlar a determinação:

Por sorte me restavam os sonhos, e em sonhos eu estava sempre numa ponte do Danúbio, às horas mortas, a fitar suas águas cor de chumbo. E soltava os pés do chão, e balançava de barriga sobre o parapeito, feliz da vida por saber que poderia, a qualquer momento, dar à minha história um desfecho que ninguém previra (BUARQUE, 2003, p.171).

Ao fim da narrativa, em sua derradeira inversão/subversão, como resposta à atitude de Kósta, o Sr.... escreve-lhe sua autobiografia, rompendo definitivamente quaisquer fronteiras entre as formas literárias. Costa/Kósta retorna então à Hungria debaixo do estrondoso sucesso da publicação de Budapeste, título que recebe sua história:

Falsificava meu vocabulário, meus pensamentos e devaneios, o canalha inventava o meu romance autobiográfico. E a exemplo da minha caligrafia forjada em seu manuscrito, a história por ele imaginada, de tão semelhante à minha, às vezes me parecia mais autêntica do que se eu próprio a tivesse escrito (BUARQUE, 2003, p.169). 


\begin{abstract}
Having as its starting point the neutral category analised by Roland Barthes in his paper on Sarrasine, written by Honoré de Balzac, and in his seminars presented in 1978 at Collège de France, this paper is an attempt to reflect on literary genres, taking also into consideration the gender as a linguistic aspect. The matter of literary genres has been one of the axis of the criticism since last century. The novel Budapeste, by Chico Buarque, is the counterpoint to deal with the theoretical question of literary genres which is also associated to language and writing, both taken as an experience.
\end{abstract}

Keywords: Gender/literary genres. Neutrality. Experience

\title{
Referências
}

AGAMBEN, Giorgio. "Infância e História; ensaio sobre a destruição da experiência". In: . Infância e História: destruição da experiência e origem da História. Belo Horizonte: Editora da UFMG, 2005. p. 9-78.

BALZAC, H. Obras Completas, Porto Alegre: Editora Globo, v.9, p.553-587.

BARTHES, Roland. "A morte do autor". In: O rumor da língua. Lisboa: Edições Setenta, 1987a. p. 49-53.

"Da obra ao texto". In: . O rumor da língua. Lisboa:

Edições Setenta, 1987b. p. 55-61.

. "Masculino, Feminino, Neutro". In: CARVALHAL, Tania

Franco et al. (Org. e trad.). Masculino, Feminino, Neutro: ensaios de semiótica narrativa. Porto Alegre: Globo, 1976.

. O grau zero da escrita: seguido de novos ensaios críticos.

São Paulo: Martins Fontes, 2004.

O neutro: anotações de aulas e seminários ministrados no Collège de France, 1977-1978. Texto estabelecido, anotado e apresentado por Thomas Clerc. São Paulo: Martins Fontes, 2003.

S/Z. Lisboa: Edições Setenta, 1999.

BENJAMIN, W. Magia e técnica, arte e política; ensaios sobre literatura e história da cultura, 1994.

BENVENISTE, Émile. Problemas de lingüística geral. São Paulo: Ed. Nacional/Ed. da USP, 1976. 
BUARQUE, Chico. Budapeste. São Paulo: Companhia das Letras, 2003.

GARRAMUÑO, Florencia. La experiencia opaca: literatura y desencanto. Buenos Aires: Fondo de Cultura Económica, 2009.

LAPLANCHE, Jean \& PONTALIS, Jean-Bertrand. Vocabulário da psicanálise. São Paulo: Martins Fontes, 1983.

SANTIAGO, Silviano. "O narrador pós-moderno". In:

Nas malhas da letra. São Paulo: Companhia das Letras, 1989. p. 38-52. 